\title{
A tsunami is approaching are you ready for it?
}

\section{Big ships versus surfboards}

We must all agree that innovations are changing our world by storm. New entities like Wikipedia, Ali Baba, Uber, AirBnB and Face book have put millions of people out of business, but created new services and business models for also millions of entrepreneurs. Everybody that stuck to the old ways in these sectors has been wiped out. These changes were not incremental but came in the form of huge waves. Companies in the past have tried to ride the waves by becoming bigger and stronger. That was a perfect strategy to ride a storm. But even the biggest of ships go under with a tidal wave. This is not the case for daring surfers on a small board. They see the tidal wave coming and take their changes. The big ships don't notice the difference and go completely under, like Eastman Kodak Inc. did while their developers were the first to come up with a digital camera. And that also took the industry of film making, chemicals and photo services with them. They all didn't see it coming. Now pictures are taken by smart phones and stored in the cloud at a price which is a fraction of the price a photo costed in the early days 20years ago!

\section{The new rules of the game}

The question is if the companies in the plant business are aware of the tsunami that is about to drop on them. In the Netherlands the development in the last 15 years has been to become bigger and reduce fixed costs by size. Science has helped them to increase efficiency by an order of magnitude in the last 70years. At the moment the Netherlands is the second largest exporter of agricultural goods in the world. Of course a lot is first imported and then re-exported again. But still we produce quite a substantial amount and about $80 \%$ of what we produce we export as well. So our main business model is trade and production for the rest of Europe. This business model is creaking. The demand for locally produced food is exponentially rising in Europe. And the consumers are the next part of the supply chain who will be in control of specifications. Retail will fall from its powerful position in the chain and will become a distribution service provider, like the rest of the chain has become already. It hasn't been done on a large scale yet, but the first companies trying to connect directly to the consumers have already been sighted. Their main obstacle now is the distribution logistics, but Uber Transport is already trying to tackle that. Apps that will personalize your food shopping towards your personal taste, health, lifestyle and budget will become mainstream soon. As soon as they feel natural to use and safe they will take a great flight. And this will change the rules of the game substantially. Anybody sticking to the old rules of the game will be wiped out.

\section{Urban horticulture is in its infancy}

The question is, “Are we ready for this change?". Most probably not, because the main companies surviving and thriving now are the greenhouse companies with more than 20 hectares of glass. Banks are financing them. Supply companies are thriving on them. However when the digital wave hits them, they will not have the ability to surf out the ride. It was in 2010 that I asked the CEO of the company Plant lab to present his vision at the International Horticultural Congress in Lisabon. I had invited a small group of plant scientists who had links to crop physiology. However many considered the commercial

\author{
Volume 7 Issue 2 - 2017
}

\author{
Olaf van Kooten \\ Department of Horticulture and Agri-business, Inholland \\ University of Applied Science, Netherlands
}

\begin{abstract}
Correspondence: Olaf van Kooten, Inholland University of Applied Science, Department of Horticulture and Agri-business, Delft, The Netherlands, Email koote00I@gmail.com
\end{abstract}

Received: May 27, 2017 | Published: May 30, 2017

growing of crops indoors as science fiction. I had the same experience in Wageningen, where the people at Plant lab were considered as cons with their claim that they could grow with a $300 \%$ efficiency gain in relation to the Dutch greenhouse growers. In the grower community everyone was convinced that this idea of indoor growing would never fly, as the sun was always cheaper. Now we see from outside of the horticultural practice community many companies trying out new techniques for what is now known as Urban Horticulture. And there are many situations I can think of where indoor growing would bring a solution that greenhouses cannot give.

\section{Can you see the wave comming?}

The same is about to happen in the marketplace. Small companies, coming from other sectors than the traditional horticultural supply chains, are testing new market techniques to bring the produce directly from the production site to the consumption place. Though they start out small and many will fail, a few will get in exactly the right spot to surf the devastating wave and come out on top unscathed. A small company named Drop box started a cloud storage system and started with about 400,000 users, they went to 4million users in 15 months. ${ }^{1}$ The real tendency in society today is that people want to do it themselves. Through $3 \mathrm{D}$ printing they can download any design and print it at home, even food. The products they buy must have a feel of closeness. The human attribute is a feeling people are craving for. Large scale production and distribution in robotic warehouse supermarkets are not part of this craving that is evolving exponentially in our society. Can we see this tsunami coming? Are we ready for it? What does it mean for plant science? What do we teach our students? Do we instil them with the drive to become a big company CEO? Or do we help them learn to ride the waves and be agile and alert?

\section{Acknowledgements}

None.

\section{Conflict of interest}

The author declares no conflict of interest.

'http://theleanstartup.com/casestudies 